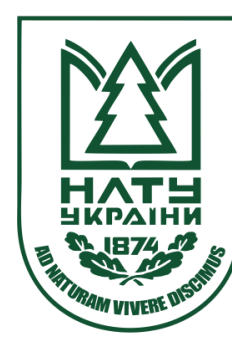

Науковий вісник НЛТУ України Scientific Bulletin of UNFU

https://nv.nltu.edu.ua

https://doi.org/10.15421/40280804

$@ \bowtie$ Correspondence author

Article received 09.10.2018 p.

Article accepted 25.10.2018 p.

V. K. Zaika

удк 630*521.1:631.1

\title{
ДІЕЛЕКТРИЧНІ ПОКАЗНИКИ ДЕРЕВНИХ ВИДІВ У ДЕРЕВОСТАНАХ ЗА УЧАСТЮ МОДРИНИ ЄВРОПЕЙСЬКОЇ
}

\begin{abstract}
Досліджено діелектричні показники прикамбіальних тканин лубу деревних видів у модринових деревостанах, які ростуть у різних лісорослинних умовах Кременецького горбогір'я. Вік деревостанів становить 12-109 років. Встановлено зниження інтенсивності життєвих процесів у модрини й інших деревних видів зі зменшенням трофності грунтів. У модрини молодняків, які ростуть в суборах і в перехідних до борів умовах, порівняно з грудами, величина імпедансу зросла істотно на $10,8-35,5 \%$, а поляризаційної ємності знизилась на $10,7-31,0 \%$. У липні-серпні показники імпедансу в модрини різного віку змінюються в межах 7,3-16,3 кОм, а поляризаційної ємності-1,25-2,51 нФ. У дуба вони, відповідно, становлять 7,114,7 кОм і 1,25-2,10 нФ. У переважній кількості деревостанів модрина і дуб характеризуються високим життєвим потенціалом. Найкращі умови для їхнього росту і функціонування складаються в мішаних деревостанах, де частка модрини становить 3-6, а дуба не більше 2-х одиниць. Найбільшими антагоністами для модрини є дуб - червоний і ясен звичайний. За їх частки у складі середньовікових деревостанів 3 і більше одиниць у модрини встановлено найвищі показники імпедансу і найнижчі поляризаційної ємності. У стиглих і перестійних деревостанах із часткою модрини 6-8 і дуба 1-3 одиниці ці деревні види проявляють високий життєвий потенціал.
\end{abstract}

Ключові слова: діелектричні показники; модрина європейська; Кременецьке горбогір'я; життєдіяльність рослин.

Вступ. Продуктивність лісових фітоценозів визначають інтенсивністю процесів життєдіяльності деревних видів. Найбільшої продуктивності досягають лісостани, в яких у процесі росту і формування складаються взаємоприйнятні взаємовідносини між його компонентами. Під час введення в лісові насадження інтродуцентів завжди був пошук відповідних аборигенних видів, які б до інтродукованого деревного виду не проявляли антагоністичних властивостей. У районі нашого дослідження наприкінці XIX - на початку XX ст. відомий лісівник-практик В. Г. Дубровинський започаткував дослідження із введення в насадження модрини європейської (Dubrovynskyi, 1973). За понад 100-річний період тут створено близько 2 тис. га насаджень за ії участю. У різних типах лісорослинних умов модрина формує чисті та мішані деревостани. У мішаних деревостанах вона росте 3 дубом звичайним і червоним, ясенем звичайним, буком лісовим, сосною звичайною, ялиною європейською, кленами гостролистим і явором, в'язем голим, грабом звичайним тощо. Її частка у складі мішаних деревостанів змінюється від поодиноких дерев до 8-9 одиниць. Абсолютно переважають деревостани 3 часткою модрини у складі деревостанів до 10-30 \% (Zaika \& Kerimov \& Ivanytskyi, 2016).

Взаємовідносини між деревними породами під час формування лісостанів впливають на інтенсивність проходження процесів життєдіяльності. Для характеристи- ки фізіологічного стану дерев у фітоценозах деякі дослідники пропонують застосовувати електрофізіологічні методи (Humeniuk, Zaika \& Bondarenko, 2012; Mac Dougall, Thompson \& Harald, 1987). У роботах А. Г. Мальцева (Maltcev, 1987), Г. Т. Криницького (Krynytskyi, 1993), Г. Т. Криницького, В. К. Заїки (Krynytskyi \& Zaika, 1995) показано зв'язок імпедансу і поляризаційної ємності зі станом дерев різних категорій росту в деревостанах. Здорові, добре розвинуті, пануючі дерева характеризуються низькими показниками імпедансу і високими - поляризаційної ємності. Ю. В. Зварич (Zvarych, 2005) вказує на зростання величини імпедансу i зниження поляризаційної ємності у дерев сосни, які ростуть у біогрупах відносно поодиноко стоячих особин. У роботі В. К. Заїки, Г. Т. Криницький, Р. С. Іваницький (Zaika, Krynytskyi \& Ivanytskyi, 2013) на підстаі вивчення діелектричних показників сосни і берези показано взаємовплив цих деревних видів під час формування 8-15 березово-соснових деревостанів природного походження на покинутих сільськогосподарських землях. Вчені встановили, що в умовах свіжого сугруду береза повисла пригнічує процеси життєдіяльності в сосни за іiі частки у складі деревостанів понад $30 \%$. Взаємовплив граба і дуба в деревостанах різного віку досліджували I. Р. Гуменюк, В. К. Заїка, В. Д. Бондаренко (Humeniuk et al., 2014; Humeniuk, Zaika \& Bondarenko, 2012). Вони встановили, що в середньовікових і

\section{Інформація про авторів:}

Керімов Ельхан Ілхамович, викладач. Email: elhan26@rambler.ru

Заїка Володимир Костянтинович, д-р біол. наук, професор, кафедра лісівництва. Email: vkzaika@ukr.net

Цитування за ДСтУ: Керімов Е. І., Заїка В. К. Діелектричні показники деревних видів у деревостанах за участю Модрини Європейської. Науковий вісник НЛтУ України. 2018, т. 28, № 8. С. 23-27.

Citation APA: Kerimov, E. I., \& Zaika, V. K. (2018). Dielectric properties of tree species in stands containing european larch. Scientific Bulletin of UNFU, 28(8), 23-27. https://doi.org/10.15421/40280804 
пристигаючих деревостанах свіжих і вологих грабових дібров Західного Поділля дуб звичайний, незалежно від його частки у складі грабово-дубових деревостанів та періоду вегетації, характеризується високим життєвим потенціалом. Найкращі умови для росту і життєдіяльності граба звичайного складаються у чистих грабняках. Уже незначна участь дуба (1-3 одиниці) у складі деревостанів призводить до пригнічення життєвих процесів у граба внаслідок посилення фітоценотичної взаємодії.

Встановлено, що $з$ погіршенням стану дерев у деревостанах діелектричні показники змінюються. Зазначено також на наявності кореляції між поляризаційною ємністю і приростом, фітомасою хвої, ступенем пошкодження дерев шкідниками (Mac Dougall, Maclean \& Thompson, 1988; Mac Dougall, Thompson \& Harald, 1987).

Отже, діелектричні показники об'єктивно характеризують стан та інтенсивність проходження процесів життєдіяльності у дерев у лісових фітоценозах. Їх доцільно використовувати під час вивчення взаємодії деревних видів у процесі формування деревостанів та впливу біотичних і абіотичних чинників довкілля (Krynytskyi, 1992; Mac Dougall, Maclean \& Thompson, 1988).
Об'єкти і методи дослідження. Об'єктом дослідження були деревостани за участю модрини європейської. Їхній вік становить 12-109 років. Докладний лісівничо-таксаційний аналіз дослідних деревостанів наведено в нашій роботі (Zaika \& Kerimov \& Ivanytskyi, 2016). Для визначення інтенсивності процесів життєдіяльності та стану деревних видів у деревостанах використали електрофізіологічні методи дослідження, а саме діелектричні показники прикамбіальних тканин лубу (Humeniuk et al., 2014). Їх визначали приладом Ф 4320. Вимірювання проводили на частоті 1 кГц. Електроди вводили в луб дерев на висоті 1,3 м. Відстань між електродами становить 2 см (Humeniuk et al., 2014).

Результати дослідження. Дослідження проведено в середині та в другій половині вегетаційного періоду (табл. 1). Молодняки ростуть від перехідного типу лісорослинних умовах свіжого боруватого субору до грудів, середньовікові- у сугрудах і грудах і пристигаючі, стиглі та перестійні - в грудах. Інтенсивність процесів життєдіяльності значно залежить від лісорослинних умов і взаємовідносин між деревними видами у фітоценозах.

Табл. 1. Діелектричні показники деревних видів у деревостанах за участю модрини європейської

\begin{tabular}{|c|c|c|c|c|c|c|c|c|}
\hline \multirow{2}{*}{$\begin{array}{c}\text { № пр. } \\
\text { пл. }\end{array}$} & \multirow{2}{*}{ Склад деревостану } & \multirow{2}{*}{$\begin{array}{l}\text { Тип } \\
\text { лісу }\end{array}$} & \multirow{2}{*}{$\begin{array}{l}\text { A, } \\
\text { років }\end{array}$} & \multirow{2}{*}{ Порода } & \multicolumn{2}{|c|}{ Імпеданс, кОм } & \multicolumn{2}{|c|}{ Поляризаційна ємність, нФ } \\
\hline & & & & & $M^{ \pm m}$ & $V, \%$ & $M^{ \pm m}$ & $\mathrm{~V}, \%$ \\
\hline$\overline{1}$ & 2 & 3 & 4 & 5 & 6 & 7 & 8 & 9 \\
\hline \multicolumn{9}{|c|}{ Серпень 2014 р. } \\
\hline \multirow{2}{*}{6} & \multirow{2}{*}{$10 \mathrm{Mдг+Ялє,} \mathrm{Ясз,} \mathrm{Бп,} \mathrm{Гз}$} & \multirow{2}{*}{$\mathrm{D}_{2-г Д}$} & \multirow{2}{*}{12} & Мдг & $7,1^{ \pm 0,2}$ & 19,3 & $2,49^{ \pm 0,08}$ & 20,2 \\
\hline & & & & Ялє & $11,8^{ \pm 0,7}$ & 34,1 & $1,73^{ \pm 0,06}$ & 20,4 \\
\hline 13 & 10Мдє+Клг, Кляс, Акб, Ос & $\mathrm{B}_{2}-д \mathrm{C}$ & 14 & Мдє & $9,3^{ \pm 0,4}$ & 29,8 & $1,87^{ \pm 0,06}$ & 23,7 \\
\hline \multirow{2}{*}{15} & \multirow{2}{*}{$9 \mathrm{M}$ дє1Сз } & \multirow{2}{*}{$\mathrm{A}_{2}-\mathrm{B}_{2}-\mathrm{C}$} & \multirow{2}{*}{25} & Мдє & $12,6^{ \pm 0,8}$ & 41,9 & $1,29^{ \pm 0,05}$ & 22,9 \\
\hline & & & & $\mathrm{C}_{3}$ & $11,1^{ \pm 0,8}$ & 32,1 & $1,50^{ \pm 0,08}$ & 22,5 \\
\hline \multirow{2}{*}{14} & \multirow{2}{*}{$8 \mathrm{Mд \epsilon 2С} 2+$ Чш } & \multirow{2}{*}{$\mathrm{B}_{2}$-дC } & \multirow{2}{*}{29} & Мдє & $10,3^{ \pm 0,3}$ & 21,0 & $1,67^{ \pm 0,06}$ & 25,7 \\
\hline & & & & $\mathrm{C}_{3}$ & $13,8^{ \pm 1,3}$ & 38,8 & $1,37^{ \pm 0,07}$ & 21,9 \\
\hline \multirow{2}{*}{11} & 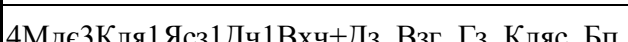 & 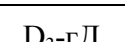 & 31 & Мдє & $7,4^{ \pm 0,2}$ & 17,4 & $2,42^{ \pm 0,10}$ & 20,7 \\
\hline & 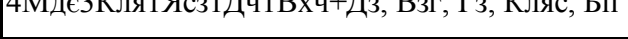 & $\mathrm{D}_{3}-\Gamma Д$ & 31 & Д3 & $7,1^{ \pm 0,1}$ & 5,0 & $2,16^{ \pm 0,07}$ & 8,2 \\
\hline & & & & Мдє & $7,3^{ \pm 0,3}$ & 20,3 & $2,36^{ \pm 0,10}$ & 23,2 \\
\hline 18 & бМДєЗЗДЗІКЛГ+КЛЯ, ЛПД, ВЗГ, 1 з, БП & $\mathrm{C}_{3}$-ГдС & 43 & Д3 & $7,9^{ \pm 0,4}$ & 28,3 & $1,90^{ \pm 0,09}$ & 30,8 \\
\hline 10 & 8Дч1Мдє1Бкл+Кля, Ясз, Гз, Взг, Лпд & $\mathrm{D}_{2}$-гД & 46 & Мдє & $12,3^{ \pm 1,1}$ & 45,9 & $1,60^{ \pm 0,10}$ & 30,7 \\
\hline 17 & 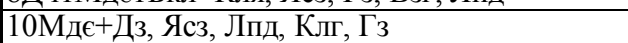 & $\mathrm{D}_{2}$-гД & 50 & Мде & $10,3^{ \pm 0,3}$ & 18,6 & $1,62^{ \pm 0,04}$ & 18,0 \\
\hline 10 & 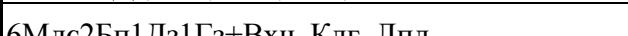 & & 50 & Мдє & $8,3^{ \pm 0,3}$ & 17,3 & $1,95^{ \pm 0,08}$ & 21,4 \\
\hline 19 & 6Мдє2ЬПІ ДзП з+Вхч, Клг, Лпд & $\mathrm{C}_{3}-\Gamma д \mathrm{C}$ & 50 & Д3 & $8,9^{ \pm 0,6}$ & 41,5 & $1,79^{ \pm 0,10}$ & 33,0 \\
\hline 5 & 2Млє2Ясз2Дч2Клг1 1з1Гз +Взг, Лпл & $\mathrm{D}_{-5}$ & 51 & Мдє & $11,0^{ \pm 0,7}$ & 31,3 & $1,41^{ \pm 0,05}$ & 19,0 \\
\hline & & $D_{2}-\Gamma Д$ & & Д3 & $7,8^{ \pm 0,4}$ & 27,0 & $1,74^{ \pm 0,08}$ & 24,7 \\
\hline 2 & 9Мє1Кля+Клг, БП, Гз & $\mathrm{D}_{2}$-гД & 52 & Мдє & $11,1^{ \pm 0,6}$ & 36,2 & $1,63^{ \pm 0,06}$ & 23,9 \\
\hline 7 & 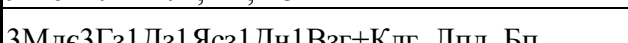 & & 52 & Мдє & $9,4^{ \pm 0,5}$ & 31,3 & $1,84^{ \pm 0,07}$ & 23,4 \\
\hline 1 & ЗКМдєЗІ зІДЗІ ЯсзІДЧІВЗГ+КЛГ, ЛПД, БП & $\mathrm{D}_{2}-Г Д$ & 52 & Д3 & $11,3^{ \pm 0,8}$ & 37,5 & $1,44^{ \pm 0,07}$ & 25,9 \\
\hline 12 & 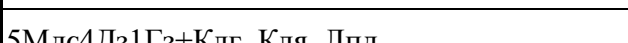 & & 53 & Мдє & $8,4^{ \pm 0,2}$ & 12,7 & $2,10^{ \pm 0,06}$ & 15,0 \\
\hline 12 & गМдє4ДЗІІ з+КлГ, Кля, ЛПД & $\mathbf{D}_{2}$-ГД & 53 & Д3 & $7,9^{ \pm 0,3} \pm$ & 18,1 & $1,98^{ \pm 0,09}$ & 19,5 \\
\hline 8 & 7Мле3 & $C_{-}-г \pi C_{-}$ & 56 & Мдє & $11,1^{ \pm 0,7}$ & 39,1 & $1,70^{ \pm 0,06}$ & 25,2 \\
\hline & 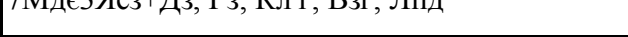 & $\mathrm{C}^{-1}$ & & Д3 & $14,7^{ \pm 1,5}$ & 33,1 & $1,25^{ \pm 0,09}$ & 16,9 \\
\hline 1 & $5 \mathrm{Mє2Ясз1Дз1Кля1Бха+Клг,} \mathrm{Взг,} \mathrm{Гз}$ & $\mathrm{D}_{2}$-гД & 58 & Мдє & $10,6^{ \pm 0,5}$ & 32,0 & $1,53^{ \pm 0,05}$ & 21,6 \\
\hline & & $\mathbf{D}_{2^{-1}}$ & & Д3 & $9,2^{ \pm 0,6}$ & 20,5 & $1,59^{ \pm 0,07}$ & 16,6 \\
\hline 9 & 7Мдє1Ялє1Ясз1 Клг+Взг. Лпд. Гз & $\mathrm{D}_{2}$-гД & 60 & Мдє & $9,8^{ \pm 0,6}$ & 39,9 & $1,92^{ \pm 0,07}$ & 25,8 \\
\hline & & & & Ялє & $11,8^{ \pm 1,4}$ & 43,1 & $1,53^{ \pm 0,11}$ & 26,5 \\
\hline 1 & 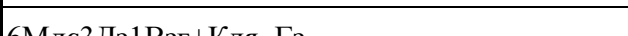 & & 81 & Мдє & $9,3^{ \pm 0,7}$ & 31,2 & $1,88^{ \pm 0,06}$ & 25,6 \\
\hline 4 & 6Мдє3ДзІВзг+Кля, Гз & $\mathrm{D}_{2}$-гД & 84 & Д3 & $8,8^{ \pm 0,5}$ & 35,3 & $2,01^{ \pm 0,08}$ & 28,3 \\
\hline 16 & -7Мде2 Ясз1 ДзБкл+КлгКляВзг & $\mathrm{D}_{2-\Gamma \Pi}$ & 101 & Мдє & $8,6^{ \pm 0,3}$ & 20,5 & $1,77^{ \pm 0,05}$ & 19,0 \\
\hline & & $D_{2^{-1}}$ & & Д3 & $8,4^{ \pm 0,4}$ & 19,9 & $1,77^{ \pm 0,07}$ & 17,4 \\
\hline 3 & $8 \mathrm{Mдє1Дз,} \mathrm{Ясз1Гз+Клг}$ & $\mathrm{D}_{2}$-гД & 109 & Мдє & $8,7^{ \pm 0,3}$ & 21,7 & $1,82^{ \pm 0,08}$ & 28,1 \\
\hline & & $\mathbf{D}_{2^{-1}}$ & & Дз & $7,3^{ \pm 0,3}$ & 26,5 & $2,10^{ \pm 0,10}$ & 28,2 \\
\hline & & Липень 2 & $15 \mathrm{p.}$ & & & & & \\
\hline 6 & $10 \mathrm{Mдг+Яле,} \mathrm{Ясз,} \mathrm{Бп,} \mathrm{Гз}$ & $\mathrm{D}_{2}$-гД & 12 & Мдг & $7,0^{ \pm 0,4}$ & 27,0 & $2,51^{ \pm 0,09}$ & 30,9 \\
\hline & & & & Яле & $9,2^{ \pm 0,6}$ & 26,5 & $2,01^{ \pm 0,08}$ & 17,6 \\
\hline 13 & 10Мде+Клг, Кляс, Акб, Ос & $\mathrm{B}_{2}$-дC & 14 & Мдє & $8,7^{ \pm 0,4}$ & 26,5 & $2,13^{ \pm 0,09}$ & 25,4 \\
\hline 15 & 9Млє $1 \mathrm{C}_{3}$ & A & 25 & Мде & $12,3^{ \pm 0,6}$ & 27,6 & $1,25^{ \pm 0,04}$ & 17,8 \\
\hline 15 & [9МдєІІ 3 & $2-\mathrm{C}$ & 25 & $\mathrm{C}_{3}$ & $10,2^{ \pm 0,5}$ & 25,5 & $1,43^{ \pm 0,06}$ & 20,6 \\
\hline 14 & $8 \mathrm{M} л 2 \mathrm{C}_{3}+$ Чш & $\mathrm{C}$ & 29 & Мде & $11,9^{ \pm 0,8}$ & 38,1 & $1,36^{ \pm 0,05}$ & 22,9 \\
\hline 14 & |ОІМДЕZС ЗТ 1ШШ & C & 29 & $\mathrm{C} 3$ & $13,8^{ \pm 1,0}$ & 30,2 & $1,16^{ \pm 0,06}$ & 21,1 \\
\hline 10 & 8Дч1Мдє1Бкл+Кля, Ясз, Гз, Взг, Лпд & $\mathrm{D}_{2}$-гД & 46 & Мдє & $16,3^{ \pm 1,9}$ & 57,4 & $1,33^{ \pm 0,11}$ & 41,3 \\
\hline
\end{tabular}

24 Науковий вісник НлтУ України, 2018, т. 28, № 8 Scientific Bulletin of UNFU, 2018, vol. 28, no 8 


\begin{tabular}{|c|c|c|c|c|c|c|c|c|}
\hline 1 & 2 & 3 & 4 & 5 & 6 & 7 & 8 & $\overline{9}$ \\
\hline 17 & $10 \mathrm{Mд \epsilon +Д3,} \mathrm{Ясз,} \mathrm{Лпд,} \mathrm{Клг,} \mathrm{Гз}$ & $\mathrm{D}_{2}$-гД & 50 & Мде & $10,8^{ \pm 0,4}$ & 19,8 & $1,60^{ \pm 0,04}$ & 21,8 \\
\hline 2 & 9Мє1Кля+Клг, Бп, Гз & $\mathrm{D}_{2}$-гД & 52 & Мде & $13,0^{ \pm 1,0}$ & 42,4 & $1,52^{ \pm 0,07}$ & 26,4 \\
\hline \multirow{2}{*}{7} & \multirow{2}{*}{ 3Мдє3Гз1Дз1Ясз1Дч1Взг+Клг, Лпд, Бп } & \multirow{2}{*}{$\mathrm{D}_{2}$-гД } & \multirow{2}{*}{52} & Мде & $9,9^{ \pm 0,5}$ & 17,5 & $1,65^{ \pm 0,08}$ & 17,8 \\
\hline & & & & Д3 & $10,3^{ \pm 0,8}$ & 44,3 & $1,51^{ \pm 0,11}$ & 31,4 \\
\hline \multirow{2}{*}{8} & \multirow{2}{*}{ 7Мдє3Ясз+Дз, Гз, Кл г, Взг, Лпд } & \multirow{2}{*}{$\mathrm{C}_{2}$-гдС } & \multirow{2}{*}{56} & Мде & $15,8^{ \pm 1,3}$ & 43,6 & $1,49^{ \pm 0,06}$ & 23,7 \\
\hline & & & & Д3 & $14,0^{ \pm 1,3}$ & 31,1 & $1,27^{ \pm 0,08}$ & 18,9 \\
\hline \multirow{2}{*}{1} & \multirow{2}{*}{ 5Мє2Ясз1Дз1Кля1Бха+Клг, Взг, Гз } & \multirow{2}{*}{$\mathrm{D}_{2-\Gamma Д}$} & \multirow{2}{*}{58} & Мде & $10,2^{ \pm 0,5}$ & 19,3 & $1,47^{ \pm 0,07}$ & 19,4 \\
\hline & & & & Д3 & $7,7^{ \pm 0,5}$ & 26,8 & $2,03^{ \pm 0,07}$ & 16,6 \\
\hline \multirow{2}{*}{9} & \multirow{2}{*}{ 7Мдє1Ялє1Ясз1Клг+Взг, Лпд, Гз } & \multirow{2}{*}{$\mathrm{D}_{2}$-гД } & \multirow{2}{*}{60} & Мде & $14,1^{ \pm 0,6}$ & 35,2 & $1,46^{ \pm 0,06}$ & 19,3 \\
\hline & & & & Ялє & $13,8^{ \pm 1,1}$ & 19,8 & $1,25^{ \pm 0,04}$ & 18,1 \\
\hline \multirow{2}{*}{4} & \multirow{2}{*}{ 6Мдє3Дз1Взг+Кля, Гз } & \multirow{2}{*}{$\mathrm{D}_{2}$-гД } & \multirow{2}{*}{84} & Мдє & $10,3^{ \pm 0,6}$ & 28,5 & $1,84^{ \pm 0,05}$ & 23,9 \\
\hline & & & & Д3 & $8,5^{ \pm 0,4}$ & 31,2 & $2,04^{ \pm 0,06}$ & 25,3 \\
\hline \multirow{2}{*}{16} & \multirow{2}{*}{ 7Мдє2Ясз1ДзБкл+КлгКляВзг } & \multirow{2}{*}{$\mathrm{D}_{2}$-гД } & \multirow{2}{*}{101} & Мде & $9,7^{ \pm 0,3}$ & 18,5 & $1,56^{ \pm 0,04}$ & 17,3 \\
\hline & & & & Д3 & $8,8^{ \pm 0,8}$ & 29,5 & $1,73^{ \pm 0,11}$ & 35,0 \\
\hline \multirow{2}{*}{3} & \multirow{2}{*}{8 Мдє1Дз, Ясз1Гз+Клг } & \multirow{2}{*}{$\mathrm{D}_{2}$-гД } & \multirow{2}{*}{109} & Мдє & $10,6^{ \pm 0,5}$ & 28,0 & $1,52^{ \pm 0,07}$ & 26,5 \\
\hline & & & & Д3 & $7,6^{ \pm 0,3}$ & 23,2 & $1,91^{ \pm 0,08}$ & 22,3 \\
\hline
\end{tabular}

Примітка: Мдє - модрина європейська, Мдг - модрина гібридна, Сз - сосна звичайна, Дз - дуб звичайний, Дч - дуб червоний, Ясз - ясен звичайний, Бкл - бук лісовий, Ялє - ялина європейська, Клг - клен гостролистий, Кля - клен-явір, Кляс клен ясенелистий, Лпд - липа дрібнолиста, Вхч - вільха чорна, Чш - черешня, Взг - в'яз голий, Бха - бархат амурський, Гз граб звичайний, Ос - осика, Бп - береза повисла, Акб - акація біла.

3 табл. 1 видно, що в молодняків величина імпедансу модрини європейської змінюється в межах 7,012,7 кОм, а поляризаційної ємності - 1,25-2,51 нФ. У дуба звичайного ці показники, відповідно, становлять 7,1 кОм і 2,16 нФ і в сосни звичайної - 10,2-13,8 кОм і 1,16-1,50 нФ. Ялина європейська росте в деревостані 3 модриною гібридною. У 12-річному віці вона характеризується відносно високою інтенсивністю функціонування. Її імпеданс виявився на рівні 9,2-11,8 кОм, а поляризаційна ємність - 1,73-2,01 нФ. Необхідно відзначити, що зі зниженням трофності грунтів спостерігаємо погіршення стану модрини європейської. Так, на ділянці 15 у свіжому боруватому суборі в модрини, порівняно 3 сосною, значно зростають показники імпедансу i знижуються поляризаційної ємності. В умовах свіжого дубового субору (пр. пл. 14) в 31-річному сосново-модриновому деревостані в модрини відносно сосни спостерігаємо зниження імпедансу і зростання поляризаційної ємності. Найкращі умови для життєдіяльності модрини і дуба складаються в грудах. На ділянці 11 у модрини і дуба спостерігаємо найнижчі показники імпедансу і найвищі поляризаційної ємності. У модрини в умовах вологої грабової діброви імпеданс істотно знизився відносно контролю на $20,4 \%\left(t_{\phi}=4,25 ; t_{05}=2,05\right)$, а поляризаційна ємність зросла на $15,5 \%\left(t_{\phi}=3,15\right)-$ табл. 2. На ділянках 15 і 16 в суборах і в перехідних до борів умовах імпеданс у модрини зріс на 10,8-46,0 \% $\left(t_{\phi}=2,00-8,94\right)$, а поляризаційна ємність знизилась на $10,7-41,3 \%\left(t_{\phi}=2,36-7,73\right)$.

У середньовікових лісостанах (вік 43-60 років) модрина росте в чистих і мішаних деревостанах із різними деревними видами. ІІї імпеданс змінюється в межах 7,316,3 кОм, а поляризаційна ємність - 1,33-2,36 нФ (див. табл. 1). Найкращі умови для життєдіяльності модрини складаються у деревостанах на пр. пл. 7, 12, 18, 19. Модрина на цих ділянках характеризується показниками імпедансу 7,3-9,9 кОм і поляризаційної ємності 1,65-2,36 нФ. Вона зазвичай істотно відрізняється за діелектричними показниками від контролю. Так, у дослідних варіантів імпеданс виявився нижчим за контроль на $8,3-20,1 \%\left(t_{\phi}=1,41-7,07\right)$, а поляризаційна ємність нижчою на $3,1-45,7 \%\left(t_{\phi}=0,56-6,87\right)-$ див. табл. 2. Модрина у складі цих деревостанів становить від 3 до 6 одиниць, а основними ii конкурентами є дуб звичайний і ясен.
Табл. 2. Достовірність різниці (t-критерій Ст'юдента) між величинами діелектричних показників модрини європейської на ділянках різного породного складу

\begin{tabular}{|c|c|c|c|c|}
\hline \multirow{2}{*}{ № пр. пл. } & \multicolumn{2}{|c|}{ Імпеданс } & \multicolumn{2}{|c|}{ Поляризаційна ємність } \\
\hline & $t_{\phi}$ & $\%$ & $t_{\phi}$ & $\%$ \\
\hline \multicolumn{5}{|c|}{ Молодняки } \\
\hline \multicolumn{5}{|c|}{ Серпень 2014 p. } \\
\hline Контроль 13 & 0,00 & 100,0 & 0,00 & 100,0 \\
\hline 6 & 4,92 & 76,3 & 6,20 & 133,2 \\
\hline 15 & 3,69 & 135,5 & 7,43 & 69,0 \\
\hline 14 & 2,00 & 110,8 & 2,36 & 89,3 \\
\hline 11 & 4,25 & 79,6 & 3,15 & 115,5 \\
\hline \multicolumn{5}{|c|}{ Липень 2015 р. } \\
\hline Контроль 13 & 0,00 & 100,0 & 0,00 & 100,0 \\
\hline 6 & 3,01 & 80,5 & 2,99 & 117,8 \\
\hline 15 & 4,99 & 141,4 & 8,94 & 58,7 \\
\hline 14 & 4,47 & 146,0 & 7,48 & 63,8 \\
\hline \multicolumn{5}{|c|}{ Середньовікові деревостани } \\
\hline \multicolumn{5}{|c|}{ Серпень 2014 р. } \\
\hline Контроль 17 & 0,00 & 100,0 & 0,00 & 100,0 \\
\hline 18 & 7,07 & 70,9 & 6,87 & 145,7 \\
\hline 10 & 1,75 & 119,4 & 0,19 & 98,8 \\
\hline 19 & 4,71 & 80,6 & 3,69 & 120,4 \\
\hline 5 & 0,92 & 106,8 & 3,28 & 87,0 \\
\hline 2 & 1,19 & 107,8 & 0,14 & 100,6 \\
\hline 7 & 1,54 & 91,3 & 2,73 & 113,6 \\
\hline 12 & 5,27 & 81,6 & 6,66 & 129,6 \\
\hline 8 & 1,05 & 107,8 & 1,11 & 104,9 \\
\hline 1 & 0,51 & 102,9 & 1,41 & 94,4 \\
\hline 9 & 0,75 & 95,1 & 3,72 & 118,5 \\
\hline \multicolumn{5}{|c|}{ Липень 2015 р. } \\
\hline Контроль 17 & 0,00 & 100,0 & 0,00 & 100,0 \\
\hline 2 & 2,04 & 120,4 & 0,99 & 95,0 \\
\hline 10 & 2,83 & 150,9 & 2,31 & 83,1 \\
\hline 7 & 1,41 & 91,7 & 0,56 & 103,1 \\
\hline 8 & 3,68 & 146,3 & 1,53 & 93,1 \\
\hline 1 & 0,94 & 94,4 & 1,61 & 91,9 \\
\hline 9 & 4,58 & 130,6 & 1,94 & 91,3 \\
\hline 16 & 2,20 & 89,8 & 0,15 & 115,0 \\
\hline 3 & 0,31 & 98,1 & 0,33 & 131,3 \\
\hline
\end{tabular}

Примітка: табличне значення $t$-критерія Стьюдента $\left(t_{05}\right)$ дорівнює 2,05; контролем були чисті модринові деревостани.

Значно гірші умови для росту i функціонування модрини європейської складаються у деревостанах на пр. пл. 2, 5, 8 і 10, де показники імпедансу в неї зросли до 11,0-16,3 кОм і відрізняються від контролю на 6,8 $50,9 \%\left(t_{\phi}=0,92-3,68\right)$, а поляризаційна ємність зменшилась до 1,33-1,60 нФ і переважно слабо на 0,6-16,9\% $\left(t_{\phi}=0,14-3,28\right)$. На ділянці 10 у складі деревостану близько $30 \%$ становить дуб червоний, який за висотою 
і діаметром не поступається модрині та проявляє до неї значну антагоністичну взаємодію. На ділянці 5 зі складом деревостану 2Мдє2Ясз2Дч2Клг1Дз1Гз+Взг, Лпд негативну дію на модрину проявляють ясен і дуб червоний, які за висотою перевищують модрину. У деревостані на пр. пл. 8 пригнічує життєдіяльність модрини ясен звичайний (Zaika \& Kerimov \& Ivanytskyi, 2016).

Життєві процеси в дуба звичайного на переважній кількості ділянок середньовікових деревостанів проходять на високому рівні. Його імпеданс варіює в межах 7,7-14,0 кОм, а поляризаційна ємність - 1,27-2,03 нФ. Значне зростання показників імпедансу і зниження поляризаційної ємності спостерігали в деревостанах на ділянках 7, 8, 9. На них дуб у складі деревостанів представлений поодинокими деревами, або не перевищує $10 \%$ (Zaika \& Kerimov \& Ivanytskyi, 2016).

У стиглих і перестійних лісостанах діелектричні показники показують, що в процесі їх формування між деревними видами склались позитивні взаємовідносини. У модрини європейської показники імпедансу змінюються в межах 8,6-10,6 кОм, а поляризаційної ємності 1,52-1,88 нФ. У дуба звичайного ці показники відповідно становили 7,3-8,8 кОм і 1,73-2,10 нФ. У процесі формування деревостанів відбувається посилення внутрішньовидової і міжвидової конкурентної боротьби, що призводить до диференціації дерев за біометричними i функціональними показниками. Ми досліджували зв'язок діелектричних показників за висотою і діаметром дерев (табл. 3).

Табл. 3. Коефіцієнти кореляції між біометричними і діелектричними показниками дерев різних видів у деревостанах

\begin{tabular}{|c|c|c|c|c|c|}
\hline \multirow{3}{*}{$\begin{array}{l}\text { № } \\
\text { пр. } \\
\text { пл. }\end{array}$} & \multirow{3}{*}{$\begin{array}{c}\text { Деревний } \\
\text { вид }\end{array}$} & \multicolumn{4}{|c|}{ Показники } \\
\hline & & \multicolumn{2}{|c|}{ діаметр } & \multicolumn{2}{|c|}{ висота } \\
\hline & & імпеданс & $\begin{array}{c}\text { поляриза- } \\
\text { ційна } \\
\text { ємність }\end{array}$ & $\begin{array}{l}\text { імпе- } \\
\text { данс }\end{array}$ & $\begin{array}{c}\text { поляриза- } \\
\text { ційна } \\
\text { ємність }\end{array}$ \\
\hline \multirow{2}{*}{6} & Мдг & $-0,726$ & 0,686 & $-0,371$ & 0,305 \\
\hline & Ялє & $-0,630$ & 0,349 & $-0,514$ & 0,177 \\
\hline 13 & Мде & $-0,596$ & 0,424 & $-0,554$ & 0,378 \\
\hline \multirow{2}{*}{15} & Мдє & $-0,175$ & 0,211 & $-0,054$ & 0,049 \\
\hline & $\mathrm{C}_{3}$ & $-0,682$ & 0,696 & $-0,561$ & 0,494 \\
\hline \multirow[t]{2}{*}{14} & Мдє & $-0,519$ & 0,631 & $-0,641$ & 0,647 \\
\hline & $\mathrm{C} 3$ & $-0,667$ & 0,671 & $-0,239$ & 0,200 \\
\hline 17 & Мдє & $-0,775$ & 0,702 & $-0,699$ & 0,609 \\
\hline 10 & Мде & $-0,412$ & 0,683 & $-0,102$ & $-0,007$ \\
\hline 2 & Мдє & $-0,410$ & 0,264 & $-0,153$ & $-0,001$ \\
\hline \multirow{2}{*}{7} & Мдє & $-0,358$ & 0,329 & $-0,619$ & 0,673 \\
\hline & Д3 & $-0,420$ & 0,221 & $-0,537$ & 0,281 \\
\hline \multirow{2}{*}{8} & Мдє & $-0,756$ & 0,751 & $-0,617$ & 0,612 \\
\hline & Д3 & $-0,458$ & 0,369 & $-0,521$ & 0,602 \\
\hline \multirow{2}{*}{1} & Мдє & $-0,338$ & $-0,238$ & $-0,678$ & 0,822 \\
\hline & Д3 & $-0,765$ & 0,746 & $-0,455$ & 0,663 \\
\hline \multirow{2}{*}{9} & Мдє & $-0,794$ & 0,594 & $-0,763$ & 0,608 \\
\hline & Ялє & $-0,377$ & $-0,136$ & $-0,672$ & 0,094 \\
\hline \multirow{2}{*}{16} & Мдє & $-0,243$ & 0,340 & $-0,220$ & 0,230 \\
\hline & Д3 & $-0,942$ & 0931 & $-0,788$ & 0,578 \\
\hline \multirow{2}{*}{3} & Мдє & $-0,640$ & 0,550 & $-0,588$ & 0,507 \\
\hline & Д3 & $-0,552$ & 0,500 & $-0,351$ & 0,339 \\
\hline
\end{tabular}

3 табл. 3 видно, що кореляційний зв'язок між біометричними і діелектричними показниками дерев різних видів у деревостанах проявляється по-різному. Встановлено, що коефіцієнт кореляції між діаметром і висотою дерев та імпедансом є оберненим, а 3 поляризаційною ємністю - прямим. Його значення змінюється від слабкого до високого і залежить від диференціації дерев в деревостанах. Зазвичай, зі збільшенням повноти деревостанів, значення коефіцієнта кореляції зростає.
На його величину впливає також санітарний стан дерев. Необхідно відзначити, що більш висока тіснота зв'язку діелектричних показників дерев проявляється 3 діаметром, аніж з висотою.

\section{Висновки:}

1. Встановлено зниження інтенсивності життєвих процесів у модрини й інших деревних видів зі зменшенням трофності грунтів. У модрини молодняків, які ростуть у суборах і в перехідних до борів умовах, порівняно 3 грудами, величина імпедансу зросла істотно на 10,8$35,5 \%$, а поляризаційна ємність знизилась на 10,7$31,0 \%$.

2. У липні-серпні показники імпедансу в модрини різного віку змінюються в межах 7,3-16,3 кОм, а поляризаційної ємності - 1,25-2,51 нФ. У дуба вони, відповідно, становлять 7,1-14,7 кОм і 1,25-2,10 нФ. Найкращі умови для їх росту і функціонування складаються в мішаних деревостанах, де частка модрини становить 3-6, а дуба - 1-2 одиниці. Найбільшими антагоністами для модрини є дуб червоний і ясен звичайний. За їх частки у складі середньовікових деревостанів 3 і більше одиниць у модрини встановлено найвищі показники імпедансу і найнижчі поляризаційної ємності. У стиглих і перестійних деревостанах із часткою модрини 6-8 та дуба червоного і ясена 1-3 одиниці, модрина і дуб звичайний проявляють високий життєвий потенціал.

\section{Перелік використаних джерел}

Dubrovynskyi, H. V. (1973). Istorychna dovidka. Surazka lisova dacha. Lviv: Kameniar, pp. 9-10. [In Ukrainian].

Humeniuk, I. R., Zaika, V. K., \& Bondarenko, V. D. (2012). Stan hraba zvychainoho v lisostanakh zapovidnyka "Medobory". (Part 1). Naukovyi visnyk Natsionalnoho universytetu bioresursiv i pryrodokorystuvannia Ukrainy: Seriia "Lisivnytstvo ta dekoratyvne sadivnytstvo", 171, 57-60. [In Ukrainian].

Humeniuk, I. R., Zaika, V. K., Bondarenko, V. D., \& Nepochatenko O. O. (Ed.). (2014). Dielektrychni pokaznyky hraba i duba v hrabovo-dubovykh derevostanakh Zakhidnoho Podillia. Perspektyvy rozvytku lisovoho ta sadovo-parkovoho hospodarstva: Materialy Mizhnarodnoyi naukovoi konferentsiyi, (pp. 108-110). Uman. [In Ukrainian].

Krynytskyi, H. T. (1992). Pro metodyku vykorystannia elektrofiziolohichnykh pokaznykiv dlia vyznachennia zhyttiezdatnosti derevnykh roslyn. Forestry, Forest, Paper and Woodworking Industry, 23, 310. [In Ukrainian].

Krynytskyi, H. T. (1993). Morfofiziolohichni osnovy selektsii derevnykh porid. Abstract of Doctoral Dissertation for Biology Sciences (06.03.01 - Forest Crops and Phytomelioration, 03.00.12 Plant physiology). Kyiv, 46 p. [In Ukrainian].

Krynytskyi, H. T., \& Zaika, V. K. (1995). Vplyv osoblyvostei formuvannia molodykh pivsibsovykh nasadzhen sosny zvychainoi na bioelektrychnu aktyvnist derev. Pryrodnychi doslidzhennia na Roztochchi, 4, 153-160. [In Ukrainian].

Mac Dougall, R., Maclean, D. A., \& Thompson, R. G. (1988). The use of electrical capacitance to determine growth and vigor of spruce and fir trees and stands in New Brunswicch. Can. J. Forest Res, 5, 587-594.

Mac Dougall, R., Thompson, R. G., \& Harald, Piene. (1987). Stem electrical capacitance and resistace measurements as relanend to total foliar biomass of balsam fir trees. Can. J. Forest Res, 17(9), 1070-1074.

Maltcev, G. A. (1987). Otcenka zhiznesposobnosti sosny elektrofiziologicheskim i vizualnym metodom. Materialy X nauchnoi konferentsiyi aspirantov $i$ nauchnykh sotrudnikov VNII lesovod. i mekhaniz. lesnogo khoziaistva, (pp. 195-198). Pushkino, April, 1. Moscow. [In Russian].

Zaika, V. K., \& Kerimov, E. I., \& Ivanytskyi, R. S. (2016). Poshyrennia ta rist modryny yevropeiskoi v umovakh Kremenetskoho horbohiria. Proceedings of the Forestry Academy of Sciences of Ukraine, 14, 45-51. [In Ukrainian]. 
Zaika, V. K., Krynytskyi, H. T., \& Ivanytskyi, R. S. (2013). Pryrodne zalisennia ta lisivnycho-ekolohichni i morfofiziolohichni osoblyvosti formuvannia lisostaniv na pokynutykh silskohospodarskykh zemliakh Pivnichno-zakhidnoho Podillia. Proceedings of the Forestry Academy of Sciences of Ukraine, 11, 41-50. [In Ukrainian].
Zvarych, Yu. V. (2005). Vplyv prostorovoi struktury derevostaniv na zhyttievist derev sosny zvychainoi. Naukovi osnovy pidvyshchennia produktyvnosti ta biolohichnoi stiikosti lisovykh ta urbanizovanykh ekosystem: Materialy LV Mizhnarodnoyi naukovo-texnichnoyi konferentsiyi profesorsko-vykladatskoho skladu, naukovykh pratsivnykiv, doktorantiv ta aspirantiv LHF NLTU Ukrainy, (pp. 3133), May 19-20, Lviv. [In Ukrainian].

Э. И. Керимов ${ }^{1}$ В. К. Заика ${ }^{2}$

${ }^{1}$ Кременеикий лесотехнический колледж, с. Белокринииа, Украина ${ }^{2}$ Национальный лесотехнический университет Украины, г. Львов, Украина

\section{ДИЭЛЕКТРИЧЕСКИЕ ПОКАЗАТЕЛИ ДРЕВЕСНЫХ ВИДОВ В ДРЕВОСТОЯХ С УЧАСТИЕМ ЛИСТВЕННИЦЫ ЕВРОПЕЙСКОЙ}

Исследованы диэлектрические показатели прикамбиальных тканей луба древесных видов в древостоях лиственницы европейской, растущих в различных типах лесорастительных условий Кременецкого холмогорья. Возраст древостоев составляет 12-109 лет. Установлено снижение интенсивности процессов жизнедеятельности у лиственницы и других древесных видов с уменьшением трофности почв. У лиственницы молодняков, которые растут в суборах и в переходных к борам условиям по сравнению с грудами показатели импеданса существенно увеличились на $10,8-35,5$ \%, а поляризиционной емкости снизились на 10,7-31,0\%. В июле-августе показатели импеданса у лиственницы разного возраста составляют 7,3-16,3 кОм, а поляризиционной емкости - 1,25-2,51 нФ. У дуба черешчатого эти показатели, соответственно, составляют 7,1-14,7 кОм и 1,25-2,10 нФ. В преобладающем количестве древостоев лиственница и дуб черешчатый характеризируются высоким жизненным потенциалом. Наилучшие условия для их роста и функционирования слаживаются в смешанных древостоях, где участие лиственницы составляет 3-6, а дуба черешчатого - 1-2 единицы. Наибольшими антагонистами для лиственницы являются дуб красный и ясень обыкновенный. При их участии в составе средневозрастных древостоев три и более единиц у лиственницы установлено наиболее высокие показатели импеданса и наименьшие - поляризационной емкости. У спелых и перестойных древостоев с участием лиственницы 6-8 и дуба красного и ясеня 1-3 единицы лиственница и дуб черешчатый проявляют высокий жизненный потенциал.

Ключевые слова: диэлектрические показатели; лиственница европейская; Кременецкое холмогорье; жизнедеятельность растений.

E. I. Kerimov', V. K. Zaika ${ }^{2}$

${ }^{I}$ Kremenetskiy Forestry College, Bilokrynytsya, Ukraine

${ }^{2}$ Ukrainian National Forestry University, Lviv, Ukraine

\section{DIELECTRIC PROPERTIES OF TREE SPECIES IN STANDS CONTAINING EUROPEAN LARCH}

The dielectric indices of the cambial tissues of the forest tree species in larch stands growing in different forest conditions of the Kremenets Hillfort, are investigated. Age of trees ranges from 12 to 109 years. The decrease of the intensity of vital processes in larch and other wood species with decreasing edaphic conditions was found. The value of impedance in the young larch trees, which grow at relatively poor edaphic region and in the trees, which grow at poor edaphic conditions, has increased significantly by $10.8-$ $35.5 \%$, comparing to young lurch growing on rich soils. At the same time, the polarization capacity of those trees decreased by $10.7-31.0 \%$. The reduction of the intensity of vital processes in pine in relation to larch towards increasing edaphic conditions was also revealed. In transient to boreal forest conditions, the value of the pine impedance was $10.2-11.1 \mathrm{kiloohm}$, and in the larch it was 12.3-12.6 kiloohm. In the regions with poor edaphic conditions, the value of impedance in pine trees increased to $13.8 \mathrm{kiloohm}$, and larch decreased to 10.3-11.9 kiloohm. In July-August, the values of impedance in larch of different ages range from 7.3 to 16.3 kilo$\mathrm{ohm}$, while the polarization capacity is $1.25-2.51 \mathrm{pF}$. In oak those values are 7.1-14.7 kiloohm and 1.25-2.10 pF respectively. In the vast majority of stands, larch and oak are characterized by high living potential. The best conditions for their growth and functioning are in mixed forest stands, where the larch share is from 3 to 6 , and oak not more than 2 units. The significant increase in the impedance and decrease in polarization capacity was observed in tree stands, where the oak was represented by single trees and does not exceed $10 \%$. The biggest antagonists for larch are red oak and common ash. If their share in the composition of medieval tree stands was 3 or more units, larch would have the highest impedance and the lowest polarization capacity. The trees in mature and primeval forests with a share of larch 6-8 trees and share of red oak with common ash were about 1-3 units show high living potential. To conclude, the correlation coefficient between the diameter and height of trees and the impedance is inverse and with the polarization capacity, it was direct. Its value ranges from low to high and depends on the trees' differentiation in tree stands. With the increase in the completeness of tree stands, the value of the correlation coefficient usually increases.

Keywords: dielectric indices; European larch; Kremenets Hillfort; plant vitality. 